\title{
Reliǵiskā identitāte un tikumi: aktualitāte audzināšanā Latvijā
}

\section{Religious Identity and Virtues: Topicality in Upbringing in Latvia}

\author{
Uǵis Nastevičs
}

21. gs. pieaugošais multikulturālisms un reliǵiju plurālisms noteica pētījuma mērķi - aprakstīt relig̣isko identitāti un tikumus Latvijas sabiedrībā. Analizēti jēdzieni. Aptaujā noskaidrotas šobrīd prevalējošās reliǵijas - kristietība un latviešu dievestība (saistīta ar latvisko dzīvesziņu un dievturību); vienlaikus pusei respondentu reliǵiskās piederības nav. Religíiozitāte un ietekme uz savu bērnu reliǵijas izvēli 20. gs. 50. un 90. gados dzimušajiem izrādījusies vājāka. Patriotisms korelē ar latviskuma veicināšanu un dzimtenes aizstāvēšanu, taisnīgums ar saticību, bet saticība - ar godbijību. Apkopoti nozīmīgākie tikumi audzināšanā, tostarp godīgums, čaklums, labestība, cieņa un mīlestība.

Atslēgvārdi: audzināšana, dievturība, latviskā dzīvesziņa, kristietība, reliǵija.

\section{Ievads}

21. gadsimtā (kad stājies spēkā bezvīzu režīms līdz ar Latvijas pievienošanos Šengenas zonai 2007. gada 21. decembrī, sekojusi 2007.-2010. gada globālā finanšu krīze un Eirozonas krīze ${ }^{1}$, 2010. gadā ieviesta pretrunīgā termiņuzturēšanās aț̣auju tirdzniecība ārzemniekiem² ${ }^{2}$, notikusi masveidīga emigrācija no Latvijas ${ }^{3}$, un jo īpaši kopš 2015. gada, kad saasinājusies Eiropas migrantu (t. s. bēgḷu) krīze ${ }^{4}$ ), Latvijas sabiedrībai arvien biežāk un izteiktāk saskaroties ar multikulturālismu un reliğiju

1 A. Bičevska, 'Cik svarīgs Latvijas tautsaimniecībai ir ārvalstu tūrists?', Latvijas Banka, 17.09.2013. Pieejams: https://www.makroekonomika.lv/cik-svarigs-latvijas-tautsaimniecibai-ir-arvalstu-turists (atsauce 20.09.2016.).

2 S. Jonāte, 'Termiņuzturēšanās aţ̦auju piešķiršanas dinamika par periodu no 2014. gada 1. jūlija līdz 2015. gada 30. jūnijam', $P M L P, 30.09 .2015$. Pieejams: http://pmlp.gov.lv/lv/ sakums/jaunumi/aktualitates/2015/09/30/termiņuzturēšanās-aţ̦auju-piešķiršanas-dinamikapar-periodu-no-2014.-gada-1.-jūlija-līdz-2015.-gada-30.-jūnijam/ (atsauce 20.09.2016.).

3 I. Mieriņa, I. Šūpule, M. Hazans, Latvijas emigrantu kopienas - pirmo pētījumu rezultātu apkopojums, Rīga, LU FSI, 2015, 41. lpp.

4 L. Taivāns, 'Bēgli sliecas pievienoties krievvalodīgajiem', Latvijas Avīze, 09.12.2015. Pieejams: http://www.la.lv/begli-sliecas-pievienoties-krievvalodigajiem/ (atsauce 20.09.2016.). 
plurālismu ${ }^{5}$, likumsakarīgi aktualizējas ne vien sabiedrības un katra indivīda etniskās un pilsoniskās, bet arī reliǵiskās identitātes jautājums, kā arī tas, cik liela loma to veidošanā ir vecākiem - audzināšanai ǵimenē un ikvienam pedagogam skolā.

Kopš 2014. gada 19. jūnija Latvijas Republikas Satversmi ievada preambula, kurā minēts: "Latvijas identitāti Eiropas kultūrtelpā kopš senlaikiem veido latviešu un lībiešu tradīcijas, latviskā dzīvesziņa, latviešu valoda, vispārcilvēciskās un kristīgās vērtības. Uzticība Latvijai, latviešu valoda kā vienīgā valsts valoda, brīvība, vienlīdzība, solidaritāte, taisnīgums, godīgums, darba tikums un ǵimene ir saliedētas sabiedrības pamats." ${ }^{\circ}$ Tā latviskā dzīvesziņa un kristīgās vêrtības kā Latvijas identitātes veidotājas iezīmē garīgos aspektus, savukārt solidaritāte, taisnīgums, godīgums, darba tikums un gimene kā saliedētas sabiedrības pamats - audzināšanas aspektus. Šajā rakstā analizēta Satversmē iekḷautā jēdziena "latviskā dzīvesziṇa" un audzināšanas principu - tikumu - nozīme Latvijas sabiedrībā.

\section{Jēdzieni literatūrā un avotos}

Audzināšana ir process, darbība, paņēmienu un pasākumu kopums, ar ko "vadīt (bērna, jaunieša) attīstību, apgādājot (viņu) ar visu eksistencei nepieciešamo, mācot morāles un uzvedības normas, veidojot dažādas praktiskas iemaņas" . Pedagogs Voldemārs Zelmenis uzsver: "Sevišķi svarīgs audzināšanas uzdevums ir jaunās paaudzes tikumiskā sagatavošana, tās iepazīstināšana ar sadzīves normām un radināšana tās konsekventi ievērot. Galvenā loma jaunā cilvēka tikumiskajā audzināšanā ir un paliek ǵimenei. Jauno personību veido tā sociālā vide, kurā viņš aug un attīstās."

Reliğiskā identitāte ir “cilvēka attieksmju, īpatnību un prakšu kopums, kas saistīts ar viṇa paša atzītu piederību kādai reliğiskai grupai" ". Valoda kā etniskās identitātes daļa un reliğiskā identitāte ir būtiski komponenti personības pašidentifikācijā. Nereti tās ir pirmās pazīmes, pēc kurām tiek nodalīti savējie un svešie ${ }^{10}$. "Eiropā

5 J. Uḷgis, 'Kristietības attieksme pret citām relig̣ijām - vai visi ceḷi ved pie Dieva?', LELB, 01.12.2008. Pieejams: http://www.lelb.lv/lv_old/?ct=vai_celi (atsauce 20.09.2016.).

6 Ievaddaļa dokumentam "Latvijas Republikas Satversme”, Rīga, 2014. Pieejams: https:// likumi.lv/doc.php?id=57980 (atsauce 17.04.2016.).

${ }^{7}$ Latviešu literārās valodas vārdnīca. 1. sēj., Rīga, Zinātne ABC, 1972, 490. lpp.

${ }^{8}$ V. Zelmenis, İss pedagogijas kurss, Rīga, Zvaigzne, 1991, 16. lpp.

${ }^{9}$ A. Misāne, Latvijas iedzīvotāju religiskās identitātes un religiozitātes dinamika pēc neatkarības atjaunošanas. Daudzveidīgās un main̄̄gās Latvijas identitātes, Rīga, LU Akadēmiskais apgāds, 2014, 284. lpp.

10 'Noslēgušies regionālie semināri projektā "Dažādība kā izglīîibas un kopienas attīstības resurss"', Izglītības attīstības centrs, 31.01.2016. Pieejams: http://www.iac.edu.lv/ noslegusies-regionalie-seminari-projekta-dazadiba-ka-izglitibas-un-kopienas-attistibasresurss/ (atsauce 17.04.2016.). 
l̦oti daudziem reliǵgiskā identitāte ir tiktāl izčākstējusi, ka vairs neveido konkurenci islāmam." "11

Tā kā priekšstati par kristīgajām vērtībām ir pietiekami skaidri definēti, šeit analizēti latviskās dz̄ivesziņas un dievturības jēdziens. Saskaņā ar centra "Zaltis" izstrādāto definīciju "Latviskā dż̄vesziņa ir tautas pieredzē balstītas, Pasaules izpratni un pārliecību veidojošās, garīgās, tikumiskās un ikdienas vērtības - kultūras tradīcija, ikdienas un svētku rituāli, gadskārtu svētki un godi, folklora, Dainas, raksta zīmes un tēli, valoda, fiziskā un garīgā veselība un izaugsme, pirts, muzicēšana un dziedāšana, maskošanās, apgēerbs un ikdienas darbu sakralizācija - rituālais dzīvesveids saskaņā ar dabu un visuma likumsakarībām, darba tikums, savstarpēja sadarbība, cieņa un atbildība"12. Salīdzinājumam - organizācijas "Latviskās dz̄ivesziņas paSaule" skaidrojums ir kodolīgs: "Latviskā dzīvesziņa ir latviešu tautas zināšanu kopums par Dievu un Dieva laisto pasauli, un tās likumiem."13 Irēna Saprovska no nodibinājuma "Māras loks" norāda uz ambivalenci starp abiem jēdzieniem: "Dievturība jeb latviskā dzīvesziņa" un "latviešu dievestība, kuru kopdami latvieši ir izveidojuši savu latvisko dzīvesziṇu"14. Folkloriste Vaira Vīķe-Freiberga latviešu dievestības jēdzienu skaidro atbilstīgi Ernesta Brastiņa savulaik postulētajām dievturības kategorijām - "latviešu dievestība, kāda tā atklājas latvju dainās un citās tautas tradīcijās, ir savā dziļākā būtībā dabas reliǵija (..) latvietim visa pasaule ir Dieva laista, visa radība ir Dieva dota un tādēl tajā nav nekā nosodāma vai nicināma. Piln̄̄gi svešs dainu garam ir grēka jēdziens, it sevišķi tāds priekšstats kā iedzimtais grēks (..) cilvēks pats nav l̦auns pēc iedzimtas būtības (..) nekur latviskās tradīcijās neredzam jēdzienu par vainas apziņu. Latviskā dievestība gan prasa Dievu turēt, atcerēties, piesaukt, daudzināt, tā prasa cien̦u un bijāšanu, bet ne zemošanos Dieva priekšă ${ }^{\prime 15}$. Satversmes preambulā norādītie audzināšanas aspekti atrodami kā tikumi E. Brastiņa "Dievtuŗu cerokslī̄" - darbīgums (darba tikums), taisnīgums (t. sk. godīgums), mīḷums (ǵimene un radi), saderīgums (solidaritāte) un dievbijīiba (t. sk. godbijības jūtas) ${ }^{16}$.

Latviskā dzīvesziņa, latviešu dievestība un dievturība ir savstarpēji cieši saistītas, un to aspekti ir izcelti Latvijas Republikas galvenā likuma - Satversmes - ievadā

11 J. Vanags, 'Viens no labākajiem risinājumiem ir uzņemt vajātos kristiešus', Apriņ̧̧is, 11.08.2015. Pieejams: http://www.aprinkis.lv/ikskiles-novads-zinas/sabiedriba/dzive-un-ticiba/item/26365-arhibiskaps-vanags-viens-no-labakajiem-risinajumiem-ir-uznemt-vajatos-kristiesus-1-dala (atsauce 17.04.2016.).

${ }^{12}$ G. Saule, 'Ir uzsākta pieteikšanās konferencei Vienošanās Latviskajā dzīvesziṇā', Latviskās Dzīvesziņas centrs ZALTIS, 02.11.2014. Pieejams: http://dziveszinazaltis.blogspot. com/2014/11/ir-uzsakta-pieteiksanas-konferencei.html (atsauce 15.04.2016.).

${ }^{13}$ I. Krūze, 'Latviskā dzīvesziņa', Latviskās dzīvesziņas paSaule, 2015. Pieejams: http://latviskadziveszina.lv/, (atsauce 15.04.2016.).

${ }^{14}$ I. Saprovska, 'Sapratne', Māras loks, 2006. Pieejams: http://www.marasloks.lv/public/?id= $52 \& \ln =1 \mathrm{v}$ (atsauce 15.04.2016.).

${ }^{15}$ V. Vīķe-Freiberga, 'Senā latviešu dievestība', Montreālas Latviešu Biedrības Ziņotājs, Nr. 444, 01.03.1986., 15.-17. 1pp.

16 E. Brastiņš, Dievtuŗu cerokslis jeb teoforu katķisms, Rīga, Latvju Dievtuŗ̧u sadraudze, 1932, 67.-76. lpp. 
līdzās kristīgajām vērtībām. Šī brīža reliǵiskā plurālisma apstākḷlos svarīgi noskaidrot, kādas reliğiskās identitātes un kāds tikumu kopums prevalē sabiedrībā, lai novērtētu atbilstību ar Satversmē paredzēto un palīdzētu pedagogiem izprast aktuālo situāciju.

\section{Metodoloǵija}

Izmantojot Google veidlapas ${ }^{17}, 2016$. gada martā tika veikta aptauja, lai izzinātu galvenās reliǵiskās grupas un tikumus Latvijas sabiedrībā, informāciju par aptauju izvietojot publiski pieejamā veidā sociālo tīklu vietnēs. Minētajā periodā tiešsaistē anketas, kas sastāv no 13 jautājumiem (11. jautājumā vairāki apgalvojumi, kuri jānovērtē Likerta skalā no 0 līdz 2), aizpildīja 345 respondenti (183 sievietes un 162 vīrieši), no tām derīgas bija 340 (180 sieviešu un 160 vīriešu) iesniegtās anketas.

\section{Pētījuma rezultāti}

Respondenti dzimuši laikā no 1931. līdz 2001. gadam. Kā pēdējo iegūto izglītību 19 (6\%) norādījuši pamatskolas, 108 (32\%) - vidusskolas, $120(35 \%)$ ir bakalaura un $93(27 \%)$ - maǵistra/doktora grāds. 43\% respondentu bērnu nav, 11\% ir pirmsskolas vecumā, $17 \%$ ir skolēni, bet $29 \%$ respondentu bērni ir pieauguši. 319 respondenti sevi izjūt kā latviešus, 10 - kā cittautiešus un $11-$ kā pie tautībām nepiederošus.

233 respondenti nepieskaita sevi pie konkrētas reliğijas, 100 ir reliǵijas sekotāji, savukārt 7 ir garīdznieki. Atvērtajā jautājumā par reliğisko piederību gūtās atbildes var apkopot sešās virskategorijās: $75(22 \%)$ - kristietība ${ }^{18}, 67(20 \%)$ - latviešu dievestība ${ }^{19}, 13(4 \%)$ - pagānisms ${ }^{20}, 11(3 \%)$ - cita ${ }^{21}, 4$ (1\%) - "Ticu Dievam” un $170(50 \%)$ respondentu norādījuši, ka viņiem reliğiskās piederības nav. Reliğiozitātes pašvērtējuma skalā (0-4) 26\% sevi novērtējuši ar $0 ; 21 \%$ - ar 1;28\% - ar 2; $19 \%$ - ar 3 un $6 \%$ - ar 4. Stabiṇu diagrammā apkopota divu prevalējošo reliǵijas virskategoriju - kristietības un latviešu dievestības sekotāju un garīdznieku reliǵiozitāte atkarībā no dzimšanas gada (sk. 1. attēlu).

Analizējot 6. jautājumā 233 tādu respondentu atbildes uz 7. jautājumu, kuri sevi pie konkrētās reliğijas nepieskaita, atklājas, ka viņu vidū atbildi "Nav" norādījuši vien $68 \%$, savukārt pārējie sadalās šādi: 11\% minējuši kristietību, 11\% latviešu dievestību, 5\% - pagānismu, 3\% - citu, bet 2\% norādījuši “Ticu Dievam”. Sadalījums rāda, ka šajā respondentu grupā, kaut arī 32\% neidentificē sevi nedz kā

${ }_{17}$ Google veidlapas, 2016. Pieejams: https://docs.google.com/forms/.

18 Virskategorijā "kristietība" apkopotas atbildes: katolis, kristietis, luterānis, luterāne ar dievturīgu domāšanu, nepraktizējošs kristīts luterānis, mesiāniskā kristietība, pagāniska katoliete, pareizticīgais, reformāts, ticu pilnam evangéēlijam.

19 Virskategorijā "latviešu dievestība" - dievturis, dievturis un senču pielūgšanas, Dievs, Laima, Māra - tautas religija, Latvietis, latvietība, latviskums, latviskā dievatziña, Latviskā dzīvesziņa, latviskā senticība, senlatviešu dzīvesziņa.

${ }^{20}$ Virskategorijā "pagānisms" - daba, pagāns, pagāninšs, pagānisms, sevi neizjūtu kā dievturi drīzāk kā pagānu.

${ }^{21}$ Virskategorijā "cita" - ateists, budists, budisms, dudeist, hindu, interesē hinduisms, hmm, islāmticīgais, pašattīstos. 
religijijas sekotājus, nedz garīdzniekus, tomēr vienlaikus tiek izjusta piederība pie konkrētas reliǵijas.

Kopumā 66\% grib, lai viṇu bērni patstāvīgi izvēlas reliǵiju savas dz̄ives laikā, bet 34\% - lai vinuu bērni ir tādi paši (reliğijas ziņā). 270 (79\%) respondentus vecāki nav ietekmējuši reliǵijas izvēlē, bet 70 (21\%) tikuši ievadīti savu vecāku reliǵijā. Respondentu viedokḷu - savu bērnu reliǵijas izvēles brīvības ziṇā - proporcija ir līdzīga neatkarīgi no viņu vecāku izdarītā lēmuma, respektīvi, piesaistītie 63\% : 37\%, bet neietekmētie - 67\% : 33\%. Arī pilsētnieku un laucinieku viedokḷu sadalījuma proporcija ir līdzīga un savstarpēji atšķiras vien $2 \%$ robežās. Pēc dzimuma dalījuma sievietes šajā jautājumā ir liberālākas (72\%:28\%) nekā vīrieši (58\% : 42\%). Savukārt pēc dzimšanas gadiem proporcija mainās šādi: 20. gs. 30. gados $67 \%: 33 \%$, 40. gados $62 \%: 38 \%$, 50. gados $78 \%: 22 \%$, 60. gados $63 \%: 37 \%, 70$. gados $60 \%: 40 \%, 80$. gados $57 \%: 43 \%, 90$. gados $78 \%: 22 \%$ un 2000. gados 100\% : 0\%. 50. gados un 90. gados dzimušo respondentu attieksme iezīmējas ievērojami liberālāka nekā viṇu priekšgājējiem - to, iespējams, var skaidrot ar režīma maiṇu, proti, Josifa Staļina nāvi 1953. gada 5. martā un Latvijas neatkarības atjaunošanu 1990. gada 4. maijā.

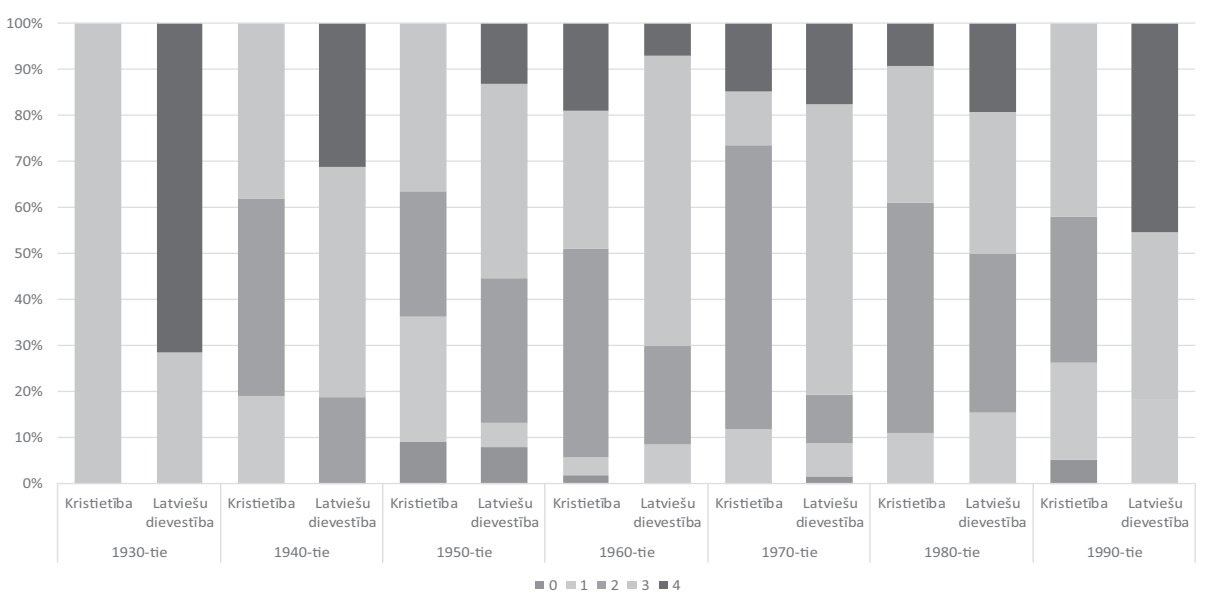

1. att. Reliǵiozitāte atkarībā no dzimšanas gada (desmitgades)

Līdzīga tendence vērojama arī reliǵiozitātes ziṇā (sk. 1. attēlu) - izteikts reliǵiozitātes zudums tieši 50. un 90. gados dzimušajiem. Vienlaikus visās desmitgadēs latviešu dievestības sekotāju un garīdznieku reliǵiozitāte izpaužas spēcīgāk nekā kristietības piekritējiem. Kaut arī padomju laiku antireliǵiskā politika ierobežoja iespējas atklāti piekopt reliǵiskus rituālus, tomēr reizēm, kulta darbības ietērpjot rotaļu, folkloras vai tradīciju kategorijā, latviešu dievestības kopēji varēja radīt izdevību izpausties, kas savukārt uz ārzemēm vērstās padomju kultūras daudzveidības apliecināšanas politikas ziņā varēja būt pat vēlami. Arī 21. gs. Latvijā darbojas vairākas folkloras kopas, kuras, ja arī neapzinās un neizcel̦ vai pat noliedz to sakrālo nozīmi, tad vismaz ārēji piekopj latviešu dievestības gadskārtu rituālus un dzīves godus. 
1. tabula

Atbildes uz 11. jautājuma apgalvojumiem 6 reliǵiju virskategoriju dalījumāa $\bar{a}^{22}$

\begin{tabular}{|c|c|c|c|c|c|c|}
\hline $\begin{array}{c}\text { Reliğiju } \\
\text { virskategorija. } \\
\text { 11. jautājuma } \\
\text { apgalvojumi }\end{array}$ & Cita & Kristietība & $\begin{array}{c}\text { Latviešu } \\
\text { dievestība }\end{array}$ & Nav & Pagānisms & $\begin{array}{c}\text { Ticu } \\
\text { Dievam }\end{array}$ \\
\hline $\begin{array}{l}\text { 1. Izmantoju iespēju } \\
\text { aizstāvēt savu } \\
\text { dzimteni } \\
\text { I take opportunity to } \\
\text { defend my fatherland }\end{array}$ & $\begin{array}{c}4 \% 48 \% \\
48 \%\end{array}$ & $\begin{array}{c}7 \% 46 \% \\
47 \%\end{array}$ & $\begin{array}{c}1 \% 27 \% \\
\underline{72 \%}\end{array}$ & $\begin{array}{c}7 \% 48 \% \\
45 \%\end{array}$ & $\begin{array}{c}4 \% 64 \% \\
32 \%\end{array}$ & $\begin{array}{c}0 \% 40 \% \\
60 \%\end{array}$ \\
\hline $\begin{array}{l}\text { 2. Esmu darbīgs, } \\
\text { enerǵisks } \\
\text { I am industrious, } \\
\text { vigorous }\end{array}$ & $\begin{array}{c}0 \% 20 \% \\
\underline{80 \%}\end{array}$ & $\begin{array}{c}0 \% 44 \% \\
56 \%\end{array}$ & $\begin{array}{c}0 \% 32 \% \\
68 \%\end{array}$ & $\begin{array}{c}1 \% 36 \% \\
63 \%\end{array}$ & $\begin{array}{c}0 \% 23 \% \\
77 \%\end{array}$ & $\begin{array}{c}0 \% 40 \% \\
60 \%\end{array}$ \\
\hline $\begin{array}{l}\text { 3. Esmu taisnīgs pret } \\
\text { sevi un citiem } \\
\text { I am just towards } \\
\text { myself and others }\end{array}$ & $\begin{array}{c}0 \% 20 \% \\
80 \%\end{array}$ & $\begin{array}{c}0 \% 34 \% \\
66 \%\end{array}$ & $\begin{array}{c}0 \% 30 \% \\
70 \%\end{array}$ & $\begin{array}{c}0 \% 29 \% \\
71 \%\end{array}$ & $\begin{array}{c}0 \% 23 \% \\
\underline{77 \%}\end{array}$ & $\begin{array}{c}0 \% 67 \% \\
33 \%\end{array}$ \\
\hline $\begin{array}{l}\text { 4. Cenšos dzīvot } \\
\text { saderīgi, saticīgi } \\
\text { Trying to live in } \\
\text { harmonious way }\end{array}$ & $\begin{array}{c}0 \% 6 \% \\
94 \% \\
\end{array}$ & $\begin{array}{c}0 \% 16 \% \\
84 \%\end{array}$ & $\begin{array}{c}0 \% 14 \% \\
\underline{86 \%}\end{array}$ & $\begin{array}{c}0 \% 18 \% \\
82 \%\end{array}$ & $\begin{array}{c}0 \% 23 \% \\
77 \%\end{array}$ & $\begin{array}{c}0 \% 18 \% \\
82 \%\end{array}$ \\
\hline $\begin{array}{l}\text { 5. Esmu godbijīgs } \\
\text { I am reverential }\end{array}$ & $\begin{array}{c}12 \% 16 \% \\
72 \% \\
\end{array}$ & $\begin{array}{c}1 \% 34 \% \\
65 \% \\
\end{array}$ & $\begin{array}{c}2 \% 31 \% \\
67 \% \\
\end{array}$ & $\begin{array}{c}3 \% 47 \% \\
50 \% \\
\end{array}$ & $\begin{array}{c}4 \% 85 \% \\
11 \% \\
\end{array}$ & $\begin{array}{c}0 \% 40 \% \\
60 \% \\
\end{array}$ \\
\hline $\begin{array}{l}\text { 6. Izjūtu sevi kā } \\
\text { Latvijas patriotu } \\
\text { I feel myself as a } \\
\text { patriot of Latvia }\end{array}$ & $\begin{array}{c}4 \% 21 \% \\
75 \%\end{array}$ & $\begin{array}{c}1 \% 14 \% \\
85 \%\end{array}$ & $\begin{array}{c}0 \% 0 \% \\
100 \% \\
\end{array}$ & $\begin{array}{c}2 \% 24 \% \\
74 \%\end{array}$ & $\begin{array}{c}0 \% 29 \% \\
71 \%\end{array}$ & $\begin{array}{c}0 \% 0 \% \\
100 \% \\
\end{array}$ \\
\hline $\begin{array}{l}\text { 7. Uzskatu, ka } \\
\text { Latvijai jābūt } \\
\text { latviskākai } \\
\text { I consider Latvia } \\
\text { should be more } \\
\text { Latvianly }\end{array}$ & $\begin{array}{c}4 \% 21 \% \\
75 \%\end{array}$ & $\begin{array}{c}1 \% 30 \% \\
69 \%\end{array}$ & $\begin{array}{c}0 \% 9 \% \\
91 \% \\
\end{array}$ & $\begin{array}{c}5 \% 22 \% \\
73 \%\end{array}$ & $\begin{array}{c}0 \% 17 \% \\
83 \%\end{array}$ & $\begin{array}{c}0 \% 18 \% \\
82 \%\end{array}$ \\
\hline $\begin{array}{l}\text { 8. Vairoju latviskumu } \\
\text { cittautiešos } \\
\text { I encourage } \\
\text { Latvianness in } \\
\text { foreigners }\end{array}$ & $\begin{array}{c}10 \% 76 \% \\
14 \%\end{array}$ & $\begin{array}{c}13 \% 64 \% \\
23 \%\end{array}$ & $\begin{array}{c}6 \% 51 \% \\
43 \% \\
\end{array}$ & $\begin{array}{c}17 \% 56 \% \\
27 \%\end{array}$ & $\begin{array}{c}0 \% 60 \% \\
40 \%\end{array}$ & $\begin{array}{c}14 \% 86 \% \\
00 \%\end{array}$ \\
\hline
\end{tabular}

${ }^{22}$ Katrā šūnā norādīiās trīs procentuālās vērtības atspoguḷo respondentu sniegto atbilžu ipatsvaru, kur katrs no 8 apgalvojumiem novērtēts Likerta skalā no 0 līdz 2 - "nekad", "reizēm/dažreiz" un "bieži/vienmēr". 
Spīrmena rangu korelācijas analīze

\begin{tabular}{|c|c|c|c|c|c|c|c|c|}
\hline & 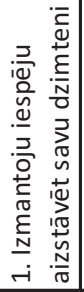 & 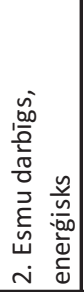 & 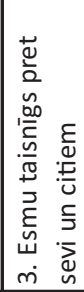 & 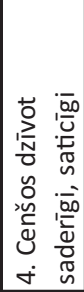 & 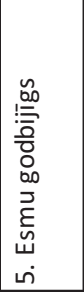 & 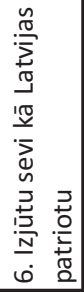 & 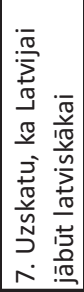 & 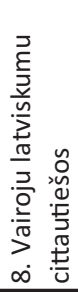 \\
\hline & & ,086 & 107" & $110^{*}$ & 086 & $447^{*}$ & $360^{* * *}$ & $352^{*}$ \\
\hline & , 086 & & $255^{* *}$ &, $200^{* *}$ & ,053 & , 047 & 071 & ,216 \\
\hline & 107" & $255^{* *}$ & & , $349^{*}$ &, $332^{* *}$ & , 132 & ,130 & $123^{*}$ \\
\hline & 110* & ,200** &, $349^{* * *}$ & & ,290** &, $132^{*}$ & ,046 & ,050 \\
\hline & ,086 & ,053 &, $332^{*}$ &, $290^{* *}$ & &, $257^{* *}$ & ,084 & ,094 \\
\hline &, $447^{* *}$ & ,047 & 132 & $132^{*}$ &, $257^{* *}$ & & ,486 & * \\
\hline &, $360^{* *}$ & 071 & , $130^{*}$ & ,046 & ,084 & , $486^{*}$ & & ,357 \\
\hline & , 352 & ,216 &, $123^{*}$ & ,050 & ,094 & , 359 & ,357 & \\
\hline
\end{tabular}

Kronbaha alfa ticamības koeficients apgalvojumiem ir $\alpha=0,872$, kas ir labs rādītājs. Visizteiktāk korelācija novērojama starp apgalvojumiem 6/7, 6/1, 1/7, 1/8, 6/8, 7/8, 3/4, 4/5 (sk. 2. tabulu). Datu analīze veikta, izmantojot IBM SPSS Statistics 22 programmu, bet diagrammas noformētas ar Microsoft Excel 2016.

\section{Nozīmīgākie tikumi audzināšanā}

340 respondenti, kā, viņuprāt, nozīmīgākos tikumus audzināšanā pavisam kopā norādījuši 1255 vienības, tostarp visbiežāk ir minēti šādi tikumi: godīgums/ godprātība (127), čaklums/darbīgums/strādīgums (60) un darba tikums (33) = (93), labestība/labsirdība/labvēlība (76), cienca (70), mīlestība/mīḷums (69), līdzcietība/ līdzjūtība/iecietība/iejūtība/empātija (44) un tolerance $(11)=(55)$, patriotisms (36), taisnīgums (35), gudrība (34), atbildība (24), uzticība (19), patstāvība/pašpietiekamība (18), godbijība (16), saticība/saskaņa/saderība (15), drosme (14), izpalīdzība (14), latviskums (14), sapratne (14), tikums/tikumiskums (14), dievbijība (13), dāsnums/ devīgums (12), ǵimeniskums (11), ticība (11), zināšanas/zinātkāre (11), dabas mīlestība/saudzēšana (10), pašapziņa/pašcieņa/pašlepnums (10), patiesums (10), rūpes (10) un citi. Šeit detalizēti uzskaitītie tikumi kopā veido divas trešdaļas no visām respondentu norādītajām vienībām.

\section{Diskusija}

Pieaugot reliǵiju plurālismam, arī Latvijā pedagogiem nākas saskarties ar arvien jauniem izaicinājumiem. Kā strādāt ar skolēniem, viṇu vecākiem un kolēǵiem, kur ikvienam var būt savs, reizēm pat visai krasi atšksirīgs garīgo vērtību un tikumu redzējums, vienlaikus saglabājot gan atbilstību valsts likumos noteiktajiem principiem, gan toleranci pret uzskatu dažādību? Jāpiekrīt V. Zelmenim, kurš akcentē 
tikumiskās audzināšanas nozīmi un gimenes galveno lomu tajā. Tomēr mūsdienās sastopam arvien vairāk vecāku, kuri neatvēl pietiekami daudz laika un uzmanības savu atvašu audzināšanai, bet gaida pedagogu atsaucību šī jautājuma risināšanā. Līdz šim lielākoties ar jēdzienu "ticības mācība" kā paralēlu izvēles mācību priekšmetu ètikai saprata vienīgi kristīgās ticības mācību ${ }^{23}$, neparedzot iespēju citu reliǵiju pārstāvjiem apgūt savas ticības mācību līdzvērtīgā apjomā. N̦emot vērā latviešu dievestības piekritēju īpatsvaru Latvijā un latviskās dzīvesziṇas nozīmību Satversmes kontekstā, izglītības saturā būtu jāparedz pienācīga vieta arī šīs reliǵijas aspektiem.

\section{Secinājumi}

Reliǵiskā identitāte ir indivīda paša atzīta piederība pie reliǵijas, un tā ir būtisks komponents personības pašidentifikācijā. Satversmes preambulā līdzās nostādītās Latvijas identitātes veidotājas - kristietība un latviskā dzīvesziṇa (kas savukārt savstarpēji ir cieši saistīta ar latviešu dievestību un dievturību) - aptaujā apstiprinās kā divas izteikti prevalējošas grupas - attiecīgi $22 \%$ un $20 \%$ - pārējām reliğijām piederošo $8 \%$ respondentu vidū. Vienlaikus pusei jeb 50\% respondentu nav nekādas reliǵiskās piederības.

Divas trešdaḷas vēlas, lai viṇu bērni patstāvīgi izvēlas reliǵiju savas dzīves laikā, turklāt sievietes ir liberālākas nekā vīrieši. 79\% respondentu viṇu vecāki nav ietekmējuši reliǵijas izvēlē. 20. gs. 50. un 90. gados, iespējams, režīma maiņas ietekmē dzimušo vidū vērojams reliǵiozitātes zudums un liberāluma pieaugums savu bērnu religigijas izvēles ziṇā.

Kopumā latviešu dievestības piekritēji ir reliǵiozāk un patriotiskāk noskaņoti nekā kristieši. Kaut arī vairums respondentu uzskata, ka Latvijai jābūt latviskākai, latviskums cittautiešos tiek vairots ievērojami kūtrāk. Patriotisms korelē ar latviskuma veicināšanu un dzimtenes aizstāvēšanu, savukārt taisnīgums korelē ar saticību, bet saticība - ar godbijību. Kā nozīmīgākie tikumi audzināšanā tiek minēti godīgums, čaklums/darba tikums, labestība, cieņa, mīlestība, iejūtība, patriotisms, taisnīgums, gudrība un atbildība.

Pētījumu ir vērts padziḷināt, analizējot Latvijas sabiedrībā aktuālās reliǵiskās prakses un to, vai un kā tās tiek iedzīvinātas bērna audzināšanas procesā gimenē un skolā.

\section{Summary}

The topicality of increase of multiculturalism and religious pluralism in the $21^{\text {st }}$ century defined the aim of this research - to explore the religious identity and virtues in the society of Latvia. The religious identity is an individual's self-acknowledged affiliation to a certain religion, being an essential component in the personality's self-identification. The prevailing religions in Latvia today were established - Christianity $22 \%$ and the Latvian religion (i.e. Dievturiba interconnected with the Latvian life wisdom) 20\% - the

23 'Kristīgā mācība skolās: fakti, problēmas, aizspriedumi', Latvijas Vēstnesis, 03.12.2004., Pieejams: https://www.vestnesis.lv/ta/id/97338 (atsauce 20.09.2016.). 
two are defined as the shaping forces of the Latvian identity in the preamble of the Constitution of the Republic of Latvia - overwhelming the 8\%, which consists of the other religions; meanwhile a half of the respondents have no religious affiliation at all.

Two thirds wish their children would choose the religion themselves, besides, women are more liberal than men. The parents of $79 \%$ of the surveyed had not influenced their choice of religion. The respondents' religiosity proved weaker and the liberal attitude toward one's children's choice of religion more prominent for those born in the 1950s and 1990s. The Latvian religion adherents are more religious and patriotic than the Christians. Although the majority feels that Latvia should be more Latvian, the encouragement of Latvianness among foreigners is considerably inert. Patriotism correlates with the encouragement of Latvianness and defense of the fatherland, righteousness - with concord, and concord - with veneration. The most significant virtues in upbringing were summarized, as follows: honesty, diligence/industry, benevolence, respect, affection, considerateness, patriotism, righteousness, wisdom and responsibility. It is worth a further analysis of the topical religious practices in the society of Latvia, including examination, whether and how they are implemented in the child's upbringing process in family and at school.

Keywords: Christianity, Dievturi, Latvian life wisdom, Latvian religion, upbringing.

\section{Informācija par autoru}

Uǵis Nastevičs, Mg. paed., Latvijas Universitātes doktorants. Pētījis japāṇu un latviešu dievestību un tikumu audzināšanas sistēmu tajās, mezglu rakstus kā latviešu valodas rakstības sistēmu un japāņu kultūras atspoguḷojumu mācību saturā Latvijā. Zinātniskās intereses - valodniecība, salīdzinošā reliǵija, japanolog̣ija, letonika un etnologija. E-pasts:jpn@inbox.lv. 